\title{
Expression of Ascaris lumbricoides putative virulence-associated genes when infecting a human host
}

\author{
Norashikin Mohd-Shaharuddin' ${ }^{1}$, Yvonne Ai Lian Lim ${ }^{1}$, Romano Ngui ${ }^{1}$ and Sheila Nathan ${ }^{2 *}$ (D)
}

\begin{abstract}
Background: Ascaris lumbricoides is the most common causative agent of soil-transmitted helminth infections worldwide, with an estimated 450 million people infected with this nematode globally. It is suggested that helminths are capable of evading and manipulating the host immune system through the release of a spectrum of worm proteins which underpins their long-term survival in the host. We hypothesise that the worm overexpresses these proteins when infecting adults compared to children to cirvumvent the more robust defence mechanisms of adults. However, little is known about the parasite's genes and encoded proteins involved during A. lumbricoides infection. Hence, this study was conducted to assess the expression profile of putative virulence-associated genes during an active infection of adults and children.

Methods: In this study, quantitative PCR was performed to evaluate the expression profile of putative virulenceassociated genes in A. lumbricoides isolated from infected children and adults. The study was initiated by collecting adult worms expelled from adults and children following anthelminthic treatment. High-quality RNA was successfully extracted from each of six adult worms expelled by three adults and three children, respectively. Eleven putative homologues of helminth virulence-associated genes reported in previous studies were selected, primers were designed and specific amplicons of $A$. lumbricoides genes were noted. The expression profiles of these putative virulence-associated genes in A. lumbricoides from infected adults were compared to those in A. lumbricoides from infected children.

Results: The putative virulence-associated genes VENOM, CADHERIN and PEBP were significantly upregulated at 166fold, 13-fold and fivefold, respectively, in adults compared to children. Conversely, the transcription of ABA-1 (fourfold), CATH-L (threefold) and INTEGRIN (twofold) was significantly suppressed in A. lumbricoides from infected adults.
\end{abstract}

\footnotetext{
*Correspondence: sheila@ukm.edu.my

${ }^{2}$ Department of Biological Sciences and Biotechnology, Faculty

of Science and Technology, Universiti Kebangsaan Malaysia, Selangor, Malaysia

Full list of author information is available at the end of the article
}

(c) The Author(s) 2021. This article is licensed under a Creative Commons Attribution 4.0 International License, which permits use, sharing, adaptation, distribution and reproduction in any medium or format, as long as you give appropriate credit to the original author(s) and the source, provide a link to the Creative Commons licence, and indicate if changes were made. The images or other third party material in this article are included in the article's Creative Commons licence, unless indicated otherwise in a credit line to the material. If material is not included in the article's Creative Commons licence and your intended use is not permitted by statutory regulation or exceeds the permitted use, you will need to obtain permission directly from the copyright holder. To view a copy of this licence, visit http://creativeco mmons.org/licenses/by/4.0/. The Creative Commons Public Domain Dedication waiver (http://creativecommons.org/publicdomain/ zero/1.0/) applies to the data made available in this article, unless otherwise stated in a credit line to the data. 
Conclusions: On the basis of the expression profile of the putative virulence-associated genes, we propose that the encoded proteins have potential roles in evasion mechanisms, which could guide the development of therapeutic

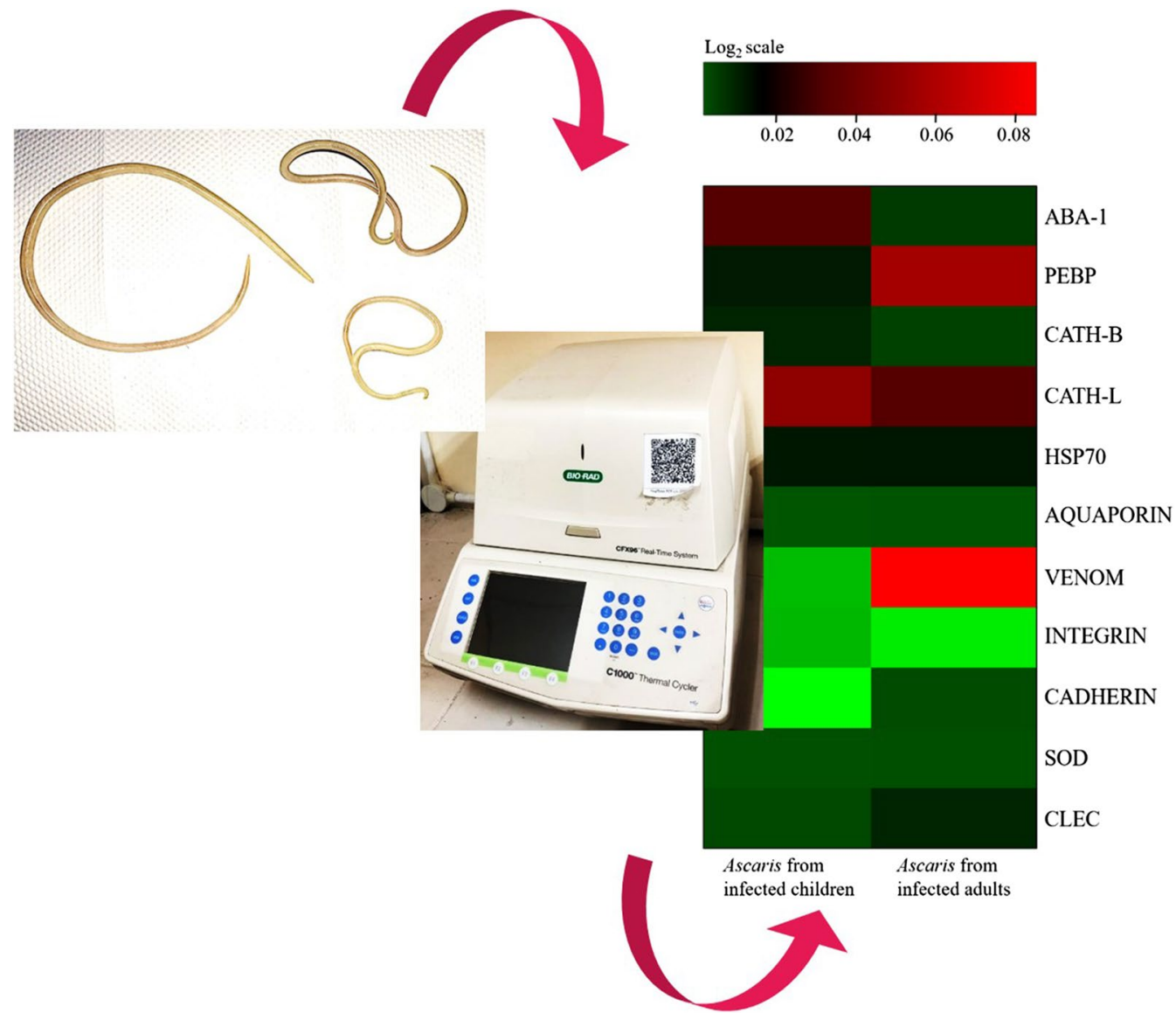

interventions.

Keywords: Ascaris lumbricoides, Virulence-associated, Immune response, Helminths

\section{Background}

Ascaris lumbricoides is a major causative agent of soiltransmitted helminth (STH) infections worldwide. According to the Global Burden of Diseases Study, in 2019, a total of 446 million cases of A. lumbricoides infection were reported globally, involving both males and females [1]. In Malaysia, the incidence of $A$. lumbricoides infection is significant and highly prevalent among the indigenous (Orang Asli) communities [2-4]. Typically, $A$. lumbricoides infection is asymptomatic. However, in heavily infected individuals, the infection can lead to upper gastrointestinal bleeding, small bowel obstruction, volvulus, intussusception, peritonitis and gastric ascariasis [5-7]. Chemotherapy (albendazole, mebendazole, levamisole and pyrantel pamoate) is routinely prescribed to curb ascariasis, particularly among children. Nonetheless, re-infection by STHs in endemic areas where clean water, sanitation and hygiene is lacking is a major drawback to controlling STHs, especially A. lumbricoides. A previous local study among the Orang Asli school children of Peninsular Malaysia reported that reinfection with $A$. lumbricoides at 6 months post-treatment was close to the baseline situation [8]. Meanwhile, in eastern Indonesia, a study described that the prevalence of $A$. lumbricoides was significantly higher than the baseline prevalence 34 months after the cessation of the mass drug administration programme [9], while in the People's Republic of China, re-infection with A. lumbricoides was reported as early as 4 months post-drug administration [10].

Environmental and behavioural features as well as host susceptibility and genetics play an important role in the chronicity and survival of parasites. Parasitic helminths' capacity to manipulate and modulate host immunity underpins their long-term survival in the host $[11,12]$, and also influences the capability of the 
host to mount effective responses towards the parasite. Understanding parasite evasion strategies in the host during infection is a compelling area of research in terms of novel drug and vaccine development. It has been proposed that the parasite evasion strategies are orchestrated through the release of molecules during the host-parasite interaction. Significant attention has focussed on the 'excretory/secretory' (ES) antigens of helminths. These ES products contribute to immune evasion strategies of the parasites through mechanisms such as shedding of surface-bound ligands and cells, alterations of lymphocyte, macrophage and granulocyte functions and modulation of other host inflammatory responses [13, 14].

With the advancement in helminth genomics, studies on ES products have revealed a set of proteins secreted by helminths, including proteases, protease inhibitors, venom-allergen homologues, glycolytic enzymes and lectins [15]. The composition of these proteins has been characterised in Brugia malayi [16], Necator americanus [17], Toxocara canis [18], Ancylostoma caninum [19] and Fasciola hepatica [20]. However, knowledge of the possible virulence mechanisms involved during A. lumbricoides infection is limited. Ascaris suum is a closely related species of $A$. lumbricoides, and in this study we proposed that homologues of $A$. suum virulence genes [21] exist in A. lumbricoides; these genes are henceforth referred to as putative $A$. lumbricoides virulence-associated genes. We examined the expression of 11 potential A. lumbricoides virulence-associated genes during an infection of adults and children.

Human protective immunity against helminths is well developed through a spectrum of immune responses, especially after prolonged exposure to the parasites. The T-helper 2 cell (Th2)-mediated immune response plays an important role in protection against intestinal helminth infection through the activation of immunerelated cells [22]. While healthy adults have an established immune defence system, young children are more vulnerable to infection [23]. Nonetheless, a strong relationship between humoral immune responses and current or future worm burdens has yet to be established [24]. This study was conducted to compare the expression levels of $A$. lumbricoides putative virulenceassociated genes from infected children and adults. We hypothesised that the expression of virulence-associated genes will be detectable in the worms obtained from both adults and children; nevertheless, the expression of these genes may be significantly higher in adults compared to children. Virulence-associated genes that are differentially modulated in the host or their encoded proteins could be key targets for the development of new drugs and vaccines. Thus, in this study we compared the expression levels of $A$. lumbricoides putative virulenceassociated genes collected from infected Malaysian indigenous adults and children.

\section{Methods \\ Gene annotation of $A$. lumbricoides putative virulence-associated genes and primer design}

Given the paucity of information for virulence-associated genes in A. lumbricoides when this project was initiated, information related to this study was inferred from previous studies on Toxocara spp. [25, 26]. Comparison of Toxocara canis draft genome sequences with those of other nematodes showed that $T$. canis genes have the highest sequence similarity to Ascaris suum, with $67.5 \%$ of the predicted T. canis genes having an orthologue in A. $\operatorname{suum}(n=11,658 ; 62.7 \%)[26]$. The A. suum genome has been sequenced [21], and this parasite is routinely used as a research model for its close relative, A. lumbricoides. Toxocara canis protein-encoding sequences were obtained from the UniProt database and subjected to a BLASTX search to identify similar protein sequences from either A. lumbricoides or A. suum (based on the availability). The $A$. lumbricoides putative virulence gene homologues were retrieved from the National Center for Biotechnology Information (NCBI) with the majority of genes uncharacterised (Table 1). A protein domain search was performed using the Conserved Domain Database (CDD) [27]. To better understand the functional distribution, Gene Ontology (GO) analysis was performed to annotate all the putative genes into three high level categories: Biological Process, Molecular Function and Cellular Component. For this analysis, the GO term 'option' was used to predict functions with default parameters and GO terms were plotted using Blast2Go [28].

Table 1 Putative Ascaris lumbricoides virulence-associated genes

\begin{tabular}{|c|c|c|}
\hline Genes & Abbreviations $^{a}$ & $\begin{array}{l}\text { Accession no. } \\
\text { (as of August } \\
\text { 2016) }\end{array}$ \\
\hline ABA-1 allergen & $A B A-1$ & U86097 \\
\hline $\begin{array}{l}\text { Phosphatidylethanolamine- } \\
\text { binding proteins }\end{array}$ & PEBP & ERG86178 \\
\hline Cathepsin-B & $C A T H-B$ & U51892 \\
\hline Cathepsin- $\mathrm{L}$ & CATH-L & AY069923 \\
\hline Heat Shock Protein 70 kDa & HSP70 & ERG79780 \\
\hline Aquaporin 3 & AQUAPORIN & ERG85246 \\
\hline Venom allergen 3 & VENOM & ERG80545 \\
\hline Integrin alpha & INTEGRIN & ERG80089 \\
\hline Cadherin & CADHERIN & ERG80754 \\
\hline Superoxide dismutase & $S O D$ & ERG81337 \\
\hline C-type lectin & CLEC & ERG84673 \\
\hline
\end{tabular}

a The abbreviations used are for this study only 
Collection of adult $A$. lumbricoides and experimental design for real-time PCR (quantitative PCR)

Prior to data collection, the study protocol was approved by the Ethics Committee of the University of Malaya Medical Centre (UMMC), Malaysia (MEC ID Number: 20144-104). Based on Kato-Katz data on indigenous people residing in Selangor, Peninsular Malaysia (Additional file 1: Table S1), a total of 14 participants with heavy and moderate infection were identified and prescribed a 3-day course of $400 \mathrm{mg}$ /daily albendazole tablets (Zentel ${ }^{\circledR}$; GlaxoSmithKline [GSK], London, UK). The participants were instructed to store the expelled worms in containers with holes, which were provided to them. As the worms were expelled from individual participants at different times, the adult worms were collected between 1 and $3 \mathrm{~h}$ post-expulsion. The worms were rinsed with distilled water and snap-frozen in liquid nitrogen. The containers with the worms were stored in liquid nitrogen dewars and transported to the laboratory where they were stored $-80^{\circ} \mathrm{C}$ prior to RNA extraction.

\section{Isolation of total RNA and CDNA synthesis}

Extraction of $A$. lumbricoides RNA was conducted using RNAse-free consumables and tools such as blades, pestle and mortar, forceps and spatula. The anterior part of the harvested frozen $A$. lumbricoides adults was crushed into powder form using a RNAse-free pestle and mortar and homogenised in $15 \mathrm{ml}$ TRIzol (Invitrogen ${ }^{\mathrm{TM}}$, Thermo Fisher Scientific, Carlsbad, CA, USA). The RNA was extracted using TRIzol, treated with DNase (Qiagen, Hilden, Germany) to remove contaminating genomic DNA and purified using the RNeasy ${ }^{\circledR}$ Mini Kit (Qiagen) according to the manufacturer's protocol. RNA integrity and concentration were determined using the Agilent 2100 Bioanalyzer (Agilent Technologies Inc., Santa Clara, CA, USA) and Nanodrop ND-1000 spectrophotometer (NanoDrop Technologies Inc., Wilmington, DE, USA), respectively. First-strand cDNA was synthesised from $1 \mu \mathrm{g}$ of total RNA of each sample using Superscript IV transcriptase following the manufacturer's instructions (Invitrogen). The synthesised cDNA samples were stored at $-20^{\circ} \mathrm{C}$ until further use.

\section{Primer design and validation}

The design of primers for the predicted A. lumbricoides virulence-associated genes was guided by the sequences of T. canis and A. suum homologues using Oligo Explorer version 1.1.2 (http://oligoexplorer.softw are.informer.com/) and synthesised by First BASE Laboratories (Selangor, Malaysia) followed by in silico PCR for verification of primer efficiency (Table 2). To obtain an optimum annealing temperature for the primers, PCR
Table 2 Primers used in quantitative PCR

\begin{tabular}{|c|c|c|c|}
\hline Genes & Sequences $\left(5^{\prime}-3^{\prime}\right)$ & Product size (bp) & $\operatorname{Tm}\left({ }^{\circ} \mathrm{C}\right)$ \\
\hline$\beta$-actin & $\begin{array}{l}\text { F: 5'-CTCGAAACAAGAATACGA } \\
\text { TG-3' } \\
\text { R: 5'-ACATGTGCCGTTGTATGA } \\
\text { TG-3' }\end{array}$ & 450 & 57 \\
\hline 185 & 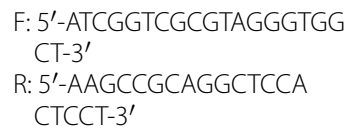 & 200 & 57 \\
\hline$A B A-1$ & $\begin{array}{l}\text { F: } \text { 5'-ACAACAAGCAACAGA }^{\prime} \text { AAAGC-3' } \\
\text { R: } \text { 5'-TGACCTCGGAAAGCA }^{\prime} \\
\text { TCT-3' }\end{array}$ & 155 & 57 \\
\hline PEBP & $\begin{array}{l}\text { F: } \text { 5'-CGATAGTGGCGTTGA }^{\text {GGT-3' }} \\
\text { R: 5'-GGAATTTGGGGGTTT } \\
\text { CAC-3' }\end{array}$ & 152 & 57 \\
\hline CATH-B & $\begin{array}{l}\text { F: } \text { 5'-GCTGCTGTAAAAGTT }^{\prime} \text { GTG-3' } \\
\text { R: 5'-AAGGTGGGAAAGGAT } \\
\text { AAG-3' }\end{array}$ & 138 & 57 \\
\hline CATH-L & $\begin{array}{l}\text { F: } \text { 5'-AGGCAAGGAGATGAA }^{\text {GTG-3' }} \\
\text { R: } \text { 5'-GCATTGTGGCTCGTA }^{\prime} \\
\text { GTA-3' }\end{array}$ & 196 & 57 \\
\hline HSP7O & $\begin{array}{l}\text { F: } 5^{\prime}-T A C A A C A A A G G C A A A C T C \\
\text { AC-3' } \\
\text { R: 5'-CTCGCATTCATCCAA } \\
\text { AAG-3' }\end{array}$ & 171 & 57 \\
\hline AQUAPORIN & $\begin{array}{l}\text { F: 5'-GGAAGAGTGAGGCGA } \\
\text { AAT-3' } \\
\text { R: } 5^{\prime}-C C G A T G A A C A G A A G C \\
\text { AAG-3' }\end{array}$ & 130 & 57 \\
\hline VENOM & $\begin{array}{l}\text { F: } \text { 5'-TCAGAGGTGGACGAC }^{\text {TAT-3' }} \\
\text { R: 5'-GACAAACGACAATGATAC } \\
\text { TG-3' }\end{array}$ & 172 & 57 \\
\hline INTEGRIN & $\begin{array}{l}\text { F: } 5^{\prime}-A T C A A C A C C C G A G C A \\
\text { ACT-3' } \\
\text { R: } 5^{\prime}-A G C C A A G C A C C A C T A \\
\text { ACTG-3' }\end{array}$ & 144 & 57 \\
\hline CADHERIN & $\begin{array}{l}\text { F: 5'-GTCAGGTCTCGTCAA } \\
\text { TCG-3' } \\
\text { R: 5'-TGGCACTTCAACATCGTA } \\
\text { G-3' }\end{array}$ & 183 & 57 \\
\hline$S O D$ & $\begin{array}{l}\text { F: } 5^{\prime}-C C C G A T T T A C C A T A C \\
\text { GAC-3' } \\
\text { R: 5'-CCACCACCATTGAAC } \\
\text { TTC-3' }\end{array}$ & 197 & 57 \\
\hline CLEC & $\begin{array}{l}\text { F: 5'-CGGCTTTGACGAGAT } \\
\text { AGAG-3' } \\
\text { R: 5'-AAGACCACCGACCAG } \\
\text { TTT-3' }\end{array}$ & 182 & 57 \\
\hline
\end{tabular}

F, Forward; R, Reverse; Tm, primer melting temperature

amplification was performed in a total volume of $20 \mu \mathrm{l}$ reaction mixture containing $10 \mu \mathrm{l}$ master mix (GeNet Bio, Chungcheongnam-do, South Korea), $2 \mu \mathrm{l}$ of each forward and reverse primer $(10 \mu \mathrm{M}), 4 \mu \mathrm{l}$ of distilled water and $2 \mu \mathrm{l}$ of cDNA template. PCR cycling was carried out 


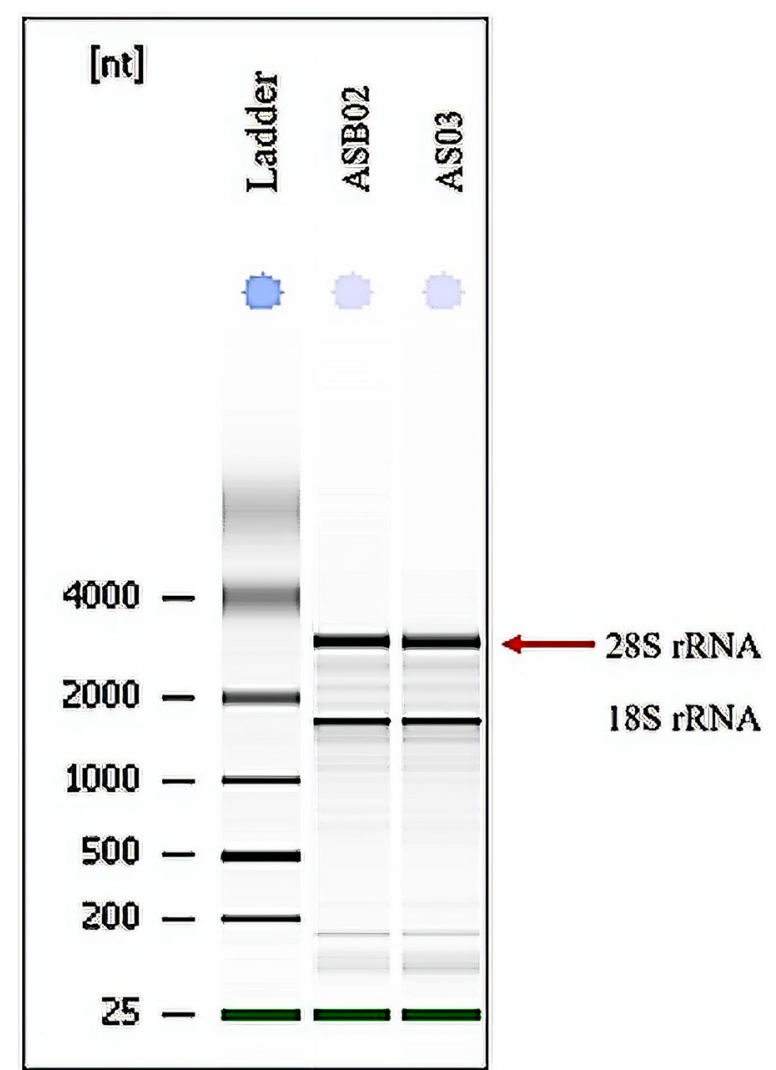

Fig. 1 Representative electrophoresis image of total RNA extracted from two biological replicates of adult Ascaris lumbricoides (AsB02 and As03), showing two distinct bands representing 285 and $18 \mathrm{~S}$ rRNA

in the $\mathrm{T} 100^{\mathrm{TM}}$ Thermal Cycler (Bio-Rad Laboratories, Inc., Hercules, CA, USA) under the following conditions were: initial denaturation at $94{ }^{\circ} \mathrm{C}, 5 \mathrm{~min}$; then denaturation at $94{ }^{\circ} \mathrm{C} / 30 \mathrm{~s}$, annealing at a temperature gradient from 55 to $60{ }^{\circ} \mathrm{C} / 30 \mathrm{~s}$ and extension at $72{ }^{\circ} \mathrm{C} / 30 \mathrm{~s}$, for 35 cycles; and a final extension at $72{ }^{\circ} \mathrm{C}$ for $7 \mathrm{~min}$. After several trials, the optimum annealing temperature was achieved at $57{ }^{\circ} \mathrm{C}$. The PCR products were visualised on a gel imager.

\section{Real-time PCR (quantitative PCR) and data analysis}

Eleven putative $A$. lumbricoides or $A$. suum gene sequences were selected based on their homology to $T$. canis virulence-associated genes reported in previous studies (Table 1). A tenfold serial dilution was performed to generate a standard curve by plotting the quantification cycle $\left(\mathrm{C}_{\mathrm{q}}\right)$ for each dilution point against the starting quantity of cDNA (100 to $0.1 \mathrm{ng}$ ) to validate the efficiency of each primer set. Standard curve analysis and quantitative PCR (qPCR) reactions were performed using Ssofast $^{\mathrm{TM}}$ Evagreen ${ }^{\circledR}$ (Bio-Rad Laboratories) according to the manufacturer's protocol on the CFX96 Touch $^{\mathrm{TM}}$ RealTime PCR Detection System (Bio-Rad Laboratories).
Standard curves were computed automatically on the average normalised $C_{q}$ value using the same real-time PCR system. The qPCR programme used was: an initial denaturation at $95{ }^{\circ} \mathrm{C}, 1 \mathrm{~min}$; followed denaturation at $95{ }^{\circ} \mathrm{C} / 30 \mathrm{~s}$, annealing at $57{ }^{\circ} \mathrm{C} / 30 \mathrm{~s}$ and extension at $76{ }^{\circ} \mathrm{C} / 30 \mathrm{~s}$, for 40 cycles; with a final extension at $60{ }^{\circ} \mathrm{C}$ for $7 \mathrm{~min}$. Data from each of the assays were normalised to the housekeeping or reference genes $\beta$-actin [29] and $18 \mathrm{~S}$ ribosomal RNA [30]. At the end of each cycle, melting curve analysis of the primers was performed by increasing the temperature by $0.5{ }^{\circ} \mathrm{C}$ from $55^{\circ} \mathrm{C}$ to $95^{\circ} \mathrm{C}$ to ensure only specific products were obtained with no formation of primer dimers. Each amplification reaction was performed in triplicate and no-template control (NTC) was included in each of the assays to monitor cross-contamination. The average $\mathrm{C}_{\mathrm{q}}$ value for each treatment group was calculated from an analysis of experimental triplicates. The expression level of the genes of interest was calculated manually using the formula $2^{-}$ $\Delta \Delta \mathrm{Cq}$ [31]. A probability level of $P<0.05$ was considered significant.

\section{Results}

Sample collection and RNA extraction

Three to five days after the 3-day anthelminthic prescription, a total of 14 adult $A$. lumbricoides were obtained from two groups of participants: (i) children (aged between 2 and 5 years old) and (ii) adults (aged $\geq 15$ years). Each individual expelled between one and two adult worms. The category of participants was made based on the availability of the samples due to the limited number of adult worms expelled from the hosts. We noted that two of the worms were female, and the rest were identified as male worms. All of the worms were of a similar size irrespective of sex and whether they were expelled by infected adult or infected child. Total RNA of individual adult $A$. lumbricoides expelled from infected children and adults was prepared and visualised on the Agilent 2100 Bioanalyzer. Based on this analysis, only six of the RNA samples (extracted from 3 worms collected from 3 children and 3 worms from 3 adults) were deemed suitable for gene expression analysis. Two distinct bands, representing $28 \mathrm{~S}$ and $18 \mathrm{~S}$ rRNA, were noted for these six selected samples (Fig. 1). The RNA integrity number (RIN) of the extracted A. lumbricoides total RNA ranged from 6.5 to 7.7 .

\section{Modulation of $A$. lumbricoides putative virulence-associated genes expression}

Eleven putative virulence-associated genes were selected; these genes encoded proteins of various functions based on previous studies on T. canis. Of these 11 genes, only eight were successfully annotated with predicted GO 
Table 3 BLASTX and Blast2GO analyses of putative Ascaris lumbricoides virulence-associated genes

\begin{tabular}{|c|c|c|c|c|c|}
\hline Genes & Gene Ontology term analysis (Blast2Go) & Gene description & Species & Identity (\%) & Evalue \\
\hline$A B A-1$ & F: retinol binding & $\begin{array}{l}\text { 1) ABA-1 allergen } \\
\text { 2) ABA-1 allergen } \\
\text { 3) Chain } A \text {, the solution structure of } \\
\text { ABA-1A saturated with oleic acid }\end{array}$ & $\begin{array}{l}\text { Ascaris lumbricoides } \\
\text { A. lumbricoides } \\
\text { A. suum }\end{array}$ & $\begin{array}{l}100 \\
99 \\
99\end{array}$ & $\begin{array}{l}6 e-144 \\
4 e-56 \\
4 e-52\end{array}$ \\
\hline PEBP & No GO terms & $\begin{array}{l}\text { 1) Phosphatidylethanolamine-binding- } \\
\text { like protein } \\
\text { 2) Phosphatidylethanolamine-binding- } \\
\text { like protein } \\
\text { 3) Phosphatidylethanolamine-binding- } \\
\text { like protein }\end{array}$ & $\begin{array}{l}\text { Toxocara canis } \\
\text { Ancylostoma duodenale } \\
\text { Teladorsagia circumcincta }\end{array}$ & $\begin{array}{l}91 \\
84 \\
78\end{array}$ & $\begin{array}{l}9 e-112 \\
2 e-89 \\
7 e-88\end{array}$ \\
\hline CATH-B & $\begin{array}{l}\text { F: cysteine-type endopeptidase activity } \\
\text { C: extracellular space } \\
\text { C: lysosome } \\
\text { P: proteolysis involved in cellular protein } \\
\text { catabolic process }\end{array}$ & $\begin{array}{l}\text { 1) Cathepsin B-like cysteine proteinase } \\
\text { 2) Cathepsin B-like cysteine proteinase } 6 \\
\text { 3) Papain family cysteine protease }\end{array}$ & $\begin{array}{l}\text { A. suum } \\
\text { T. canis } \\
\text { Haemonchus contortus }\end{array}$ & $\begin{array}{l}100 \\
84 \\
76\end{array}$ & $\begin{array}{l}0.0 \\
0.0 \\
0.0\end{array}$ \\
\hline HSP70 & No GO terms & $\begin{array}{l}\text { 1) Uncharacterised protein C30C11.4 } \\
\text { 2) Hypothetical protein WUBG_09411 } \\
\text { 3) Hypothetical 86.9-kDa protein } \\
\text { C30C11.4 in chromosome III, putative }\end{array}$ & $\begin{array}{l}\text { T. canis } \\
\text { Wuchereria bancrofti } \\
\text { Brugia malayi }\end{array}$ & $\begin{array}{l}91 \\
65 \\
64\end{array}$ & $\begin{array}{l}0.0 \\
0.0 \\
0.0\end{array}$ \\
\hline CATH-L & $\begin{array}{l}\text { F: cysteine-type endopeptidase activity } \\
\text { F: serine-type endopeptidase activity } \\
\text { F: protein binding } \\
\text { C: extracellular space } \\
\text { C: lysosome } \\
\text { C: vesicle lumen } \\
\text { C: yolk granule } \\
\text { P: proteolysis involved in cellular protein } \\
\text { catabolic process }\end{array}$ & $\begin{array}{l}\text { 1) Cathepsin } L \\
\text { 2) Cathepsin L } \\
\text { 3) Cathepsin L family }\end{array}$ & $\begin{array}{l}\text { A. suum } \\
\text { T. canis } \\
\text { Caenorhabditis elegans }\end{array}$ & $\begin{array}{l}100 \\
89 \\
82\end{array}$ & $\begin{array}{l}2 e-121 \\
4 e-107 \\
8 e-102\end{array}$ \\
\hline AQUAPORIN & $\begin{array}{l}\text { F: channel activity } \\
\text { C: membrane } \\
\text { P: transmembrane transport }\end{array}$ & $\begin{array}{l}\text { 1) Aquaporin-3 } \\
\text { 2) Aquaporin-1 } \\
\text { 3) Aquaporin-1 }\end{array}$ & $\begin{array}{l}\text { T. canis } \\
\text { T. canis } \\
\text { T. canis }\end{array}$ & $\begin{array}{l}94 \\
93 \\
93\end{array}$ & $\begin{array}{l}5 e-113 \\
0.0 \\
0.0\end{array}$ \\
\hline VENOM & C: extracellular region & $\begin{array}{l}\text { 1) Venom allergen } 5 \\
\text { 2) Ancylostoma secreted protein } \\
\text { 3) Ancylostoma secreted protein }\end{array}$ & $\begin{array}{l}\text { T. canis } \\
\text { T. canis } \\
\text { T. canis }\end{array}$ & $\begin{array}{l}58 \\
51 \\
50\end{array}$ & $\begin{array}{l}6 e-30 \\
3 e-65 \\
2 e-62\end{array}$ \\
\hline$S O D$ & $\begin{array}{l}\text { F: superoxide dismutase activity } \\
\text { F: metal ion binding } \\
\text { P: removal of superoxide radicals } \\
\text { P: oxidation-reduction process }\end{array}$ & $\begin{array}{l}\text { 1) Superoxide dismutase (Mn) 1, mito- } \\
\text { chondrial } \\
\text { 2) Manganese superoxide dismutase } \\
\text { 3) Mitochondrial manganese superoxide } \\
\text { dismutase }\end{array}$ & $\begin{array}{l}\text { T. canis } \\
\text { Ditylenchus destructor } \\
\text { Bursaphelenchus mucronatus }\end{array}$ & $\begin{array}{l}90 \\
75 \\
73\end{array}$ & $\begin{array}{l}5 e-131 \\
3 e-111 \\
6 e-114\end{array}$ \\
\hline INTEGRIN & No GO terms & $\begin{array}{l}\text { 1) Integrin alpha pat-2 } \\
\text { 2) Integrin alpha pat-2 } \\
\text { 3) Hypothetical protein WUBG_12493 }\end{array}$ & $\begin{array}{l}\text { T. canis } \\
\text { Loa loa } \\
\text { W. bancrofti }\end{array}$ & $\begin{array}{l}89 \\
78 \\
77\end{array}$ & $\begin{array}{l}0.0 \\
0.0 \\
1 \mathrm{e}-155\end{array}$ \\
\hline CADHERIN & $\begin{array}{l}\text { F: calcium ion binding } \\
\text { C: plasma membrane } \\
\text { P: homophilic cell adhesion via plasma } \\
\text { membrane adhesion molecules } \\
\text { C: integral component of membrane }\end{array}$ & $\begin{array}{l}\text { 1) Protocadherin-16 } \\
\text { 2) Cadherin domain protein } \\
\text { 3) Cadherin domain containing protein }\end{array}$ & $\begin{array}{l}\text { T. canis } \\
\text { Ancylostoma ceylanicum } \\
\text { H. contortus }\end{array}$ & $\begin{array}{l}77 \\
33 \\
40\end{array}$ & $\begin{array}{l}9 e-164 \\
3 e-11 \\
5 e-62\end{array}$ \\
\hline CLEC & $\begin{array}{l}\text { F: transmembrane signalling receptor } \\
\text { activity } \\
\text { C: extracellular region } \\
\text { C: integral component of plasma } \\
\text { membrane } \\
\text { F: carbohydrate binding } \\
\text { F: monosaccharide binding }\end{array}$ & $\begin{array}{l}\text { 1) C-type lectin } \\
\text { 2) C-type lectin domain containing } \\
\text { protein } \\
\text { 3) C-type lectin domain family } 4 \text { mem- } \\
\text { ber E-like }\end{array}$ & $\begin{array}{l}\text { C. elegans } \\
\text { H. contortus } \\
\text { Pelodiscus sinensis }\end{array}$ & $\begin{array}{l}26 \\
26 \\
33\end{array}$ & $\begin{array}{l}1 e-07 \\
2 e-06 \\
1 e-06\end{array}$ \\
\hline
\end{tabular}

terms (Table 3). The predicted functions of these genes are listed in Additional file 1: Table S2. When we initiated this study, the selected $A$. lumbricoides genes had not been previously annotated due to the absence of a complete genome sequence and are therefore referred to here as putative virulence-associated genes. In lieu of 


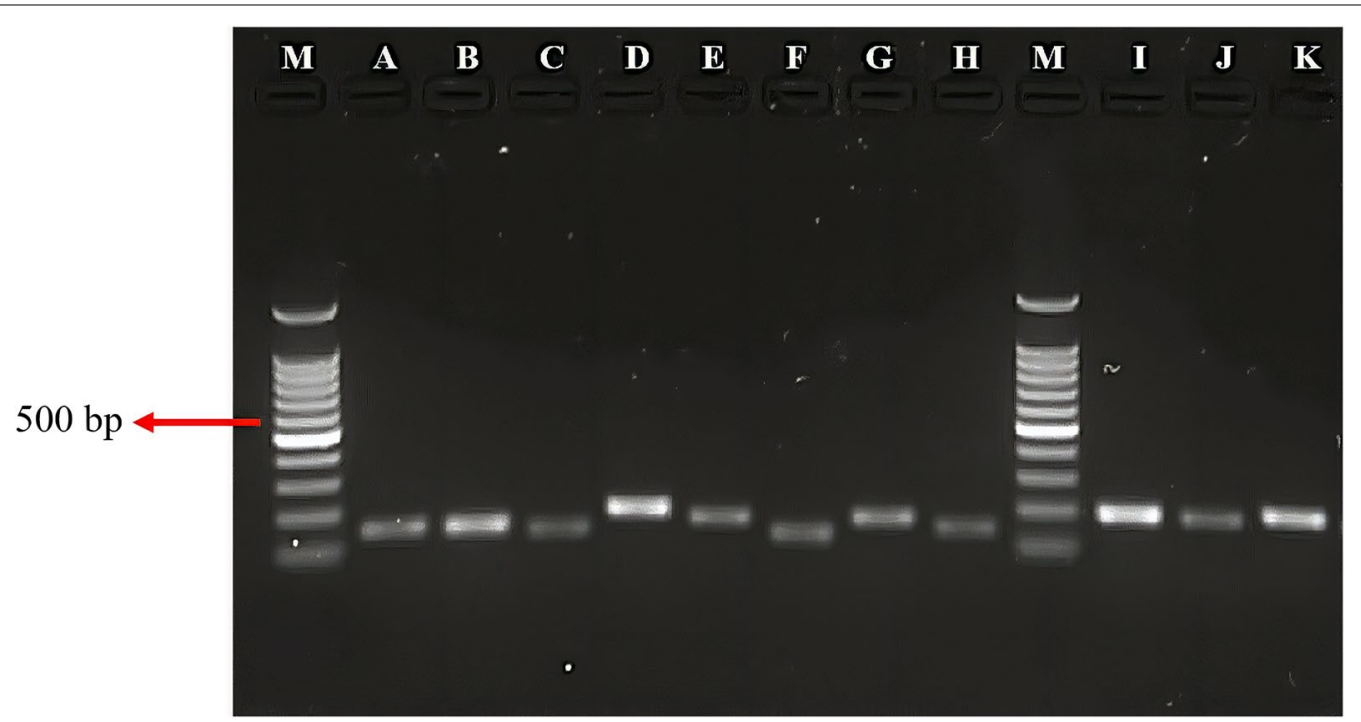

Fig. 2 Specific amplicons of putative virulence-associated genes amplified from A. lumbricoides cDNA. Lanes: M 100-bp ladder, AABA-1 (155 bp), BPEBP (152 bp), CCATH-B (138 bp), D CATH-L (196 bp), EHSP70 (171bp), FAQUAPORIN (130bp), GVENOM (172 bp), HINTEGRIN (144bp), I SOD (197 bp), JCADHERIN (183 bp), KCLEC (182 bp)

this limitation, the designed primers were subjected to an initial screen by gradient PCR. Specific amplicons with a common annealing temperature of $57^{\circ} \mathrm{C}$ were clearly observed for all 11 genes (Fig. 2). Ascaris lumbricoides cDNA was subsequently serial diluted tenfold $(100,10,1$ and $0.1 \mathrm{ng}$ ), and the standard curve plotted for each dilution point revealed primer efficiency of between 90 and $110 \%$, except for HSP70 (86.8\%) and INTEGRIN (138.9\%) (Additional file 1: Table S3).

Once the specificity of the newly designed primers was confirmed, qPCR was performed on cDNA prepared from adult worms expelled by the local indigenous adults and children sampled in this study. qPCR data were normalised to the housekeeping or reference genes $\beta$-actin [29] and 18S ribosomal RNA [30]. The average $C_{q}$ value for each treatment group was calculated and expression levels were determined using the formula $2^{-\Delta \Delta \mathrm{Cq}}[31]$. As noted earlier, we hypothesised that worms expelled by adults may display higher level of virulence in an attempt to avoid the highly developed adult host defence response. Hence, the expression profile of A. lumbricoides from infected adults was compared to that of worms from infected children (Fig. 3a). The comparative analysis demonstrated that VENOM was highly upregulated (166-fold, $P<0.05$ ) in adults compared to children while the expression of both CADHERIN and PEBP was elevated significantly $(P<0.05)$ at 13 -fold and fivefold, respectively. Conversely, the transcription of $A B A-1$ (fourfold), CATH-L (threefold) and INTEGRIN (twofold) was significantly downregulated $(P<0.05)$ in $A$. lumbricoides from infected adults (Fig. 3b).

\section{Discussion}

To the best of our knowledge, this is the first study to profile the gene expression of $A$. lumbricoides putative virulence-associated genes during infection in adults and children from an endemic area in Malaysia. Ascaris lumbricoides is the most common helminthic infection of humans [32]. In highly endemic communities, it is more common to find individuals infected with a small number of worms and only a handful of individuals in the community present with a high worm burden. Parasite establishment in a community is dependent on the dynamics of host-parasite interactions or aggregation whereby only a few individuals harbour high intensity infections [33]. In endemic communities, it is common for re-infection with this parasite to occur within a few months of repeated large-scale administrations of anthelmintic drugs [34]. Information on the pathogenesis of A. lumbricoides is limited and mainly implied based on the understanding of its close relative, A. suum. Evaluating A. lumbricoides virulence by examining the expression of virulence-associated genes during infection may shed light on how this parasite survives in the host as well as provide new targets for drug design and intervention. Hence, the goal of this study was to quantify the expression levels of $A$. lumbricoides putative virulence-associated genes during an infection of adults and children. While many nematode genome sequences are available, information on the $A$. lumbricoides genome at the start of this study was limited to its mitochondrial genome [35]. Given this limitation, the identification of $A$. lumbricoides virulence genes was based on the results from previous studies on $T$. canis to 

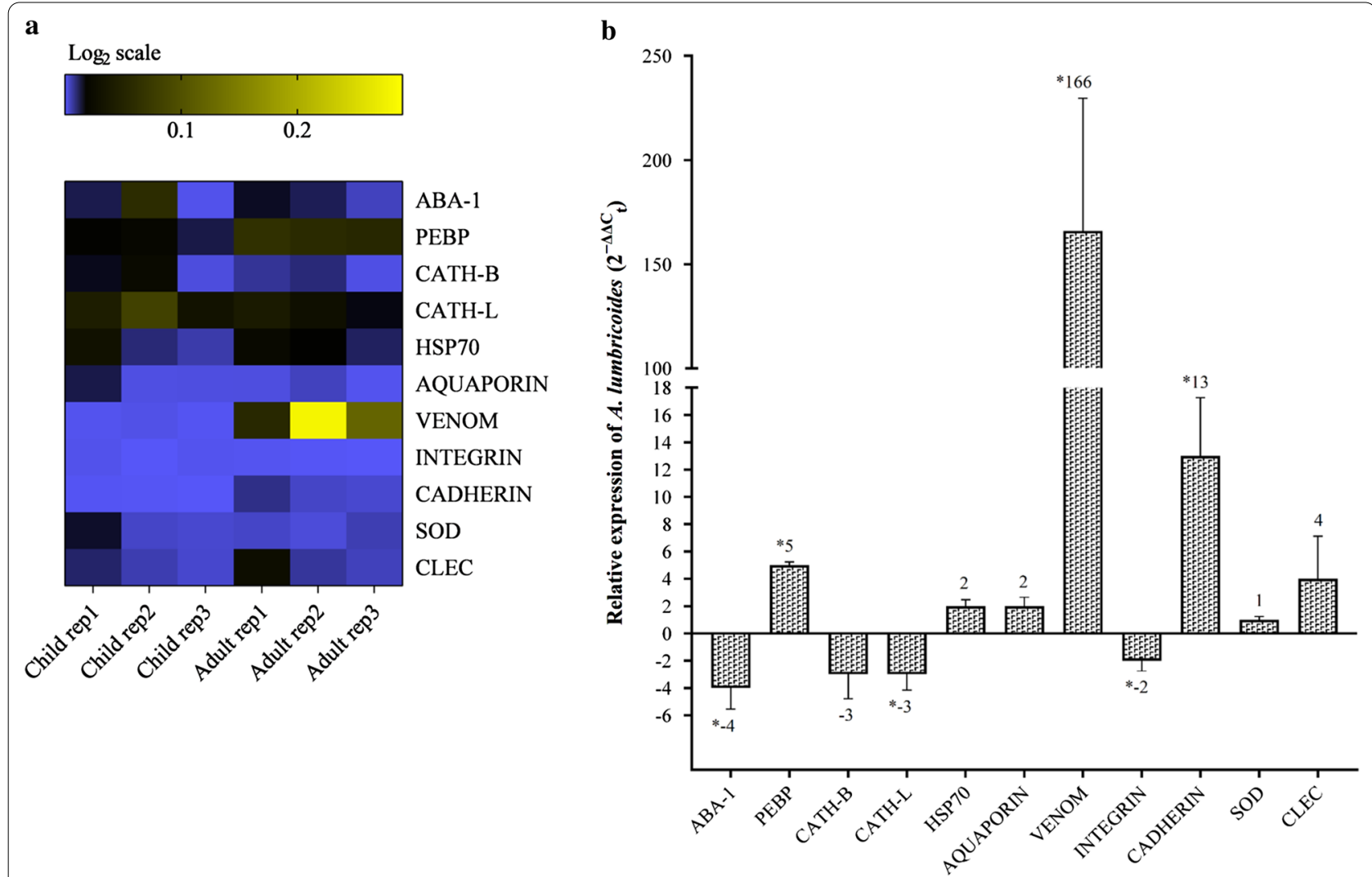

Fig. 3 a Heat map visualisation of differences in gene expression between putative virulence-associated genes in A. lumbricoides from infected adults relative to $A$. lumbricoides from infected children. Coloured scales in the heat map represent $\log _{2}$ fold change values, with blue representing downregulated genes and yellow representing upregulated genes. Child rep1, child rep2, child rep3 represent individual A. lumbricoides from infected children; adult rep1, adult rep2, adult rep3 represent $A$. lumbricoides from infected adults. b Relative expression of putative virulence-associated genes in A. lumbricoides from infected adults relative to A. lumbricoides from infected children. A normalised ratio ( $Y$-axis) representing the $2^{-\Delta \Delta C q}\left(=2^{-\Delta \Delta C q}\right)$ value of $>1$ indicates upregulation, whereas a ratio of less than -1 indicates downregulation. Asterisk indicates a significant difference at $P<0.05$. The number above the respective bar represents the fold-change for each gene. Note: $2^{-\Delta \Delta C a}$ represents the difference in $\Delta C_{q}$ values between the adult- and children-derived worm samples normalised to reference housekeeping genes

predict A. suum homologous sequences. A comparison of the A. suum draft genome sequence [21] with that of other species indicated that $T$. canis genes had the highest sequence similarity to $A$. suum [26]. With the recent publication of the $A$. lumbricoides genome (Acc. No. SMSY010000002.1) [36], we were able to confirm that the sequences of the selected $A$. lumbricoides genes are between 96.4 and $100 \%$ identical to the A. suum gene sequences.

Over time, parasites have developed a remarkable set of molecular adaptations that manipulate, inhibit or activate different host cells or pathways to maximise their success in the host $[12,15]$. Numerous groups of proteins have been suggested to play major biological roles in host-parasite interactions [37], including the sperm-coat protein (SCP)-like extracellular proteins (SCP/TAPS proteins). This family of proteins is also called SCP/Tpx-1/Ag5/ PR-1/Sc7 (SCP/TAPS; Pfam: PF00188) and belongs to the cysteine-rich secretory protein (CRISP) superfamily $[38,39]$. In the present study, expression of the A. lumbricoides venom allergen 3 (VENOM) gene was significantly upregulated, at 166 -fold $(P<0.05)$, in worms isolated from infected adults compared to A. lumbricoides isolated from infected children. The venom allergen protein is homologous to the SCP/TAPS protein [16, 40]. SCP/ TAPS homologues have been characterised for a range of helminth species, including Schistosoma mansoni [38], Ancylostoma caninum [19, 41], Necator americanus [17], Haemonchus contortus [42], Onchocerca volvulus [43, 44], T. canis [26, 45], and Brugia malayi [16].

In $A$. caninum, SCP/TAPS proteins are known as activation-associated proteins (ASPs). There are two types of ASPs: double- and single-domain ASPs, designated as Ac-ASP-1 and Ac-ASP-2, respectively. These proteins are secreted in response to host-specific signals during the infection process [46]. More recently, 
four additional ASPs have been characterised in adult A. caninum, namely Ac-ASP-3, Ac-ASP-4, Ac-ASP-5 and Ac-ASP-6, while Ac-ASP-7 is highly expressed in the $A$. caninum larvae during transition from the freeliving to parasitic stage [47]. In addition, another study on A. caninum ASPs revealed that these proteins are the most abundantly characterised in serum-activated third-stage larvae (L3s) [48] and ASPs also dominate the ES proteins released by these worms [49]. Another SCP/ TAPS molecule, referred to as neutrophil inhibitory factor (NIF), was first isolated from adult A. caninum and has been shown to play an immunomodulatory role by blocking the adhesion of activated neutrophils to vascular endothelial cells and the subsequent release of $\mathrm{H}_{2} \mathrm{O}_{2}$ from activated neutrophils [50]. In addition, Ac-ASP-1 and Ac-ASP-2 homologues have also been identified in the L3s of $N$. americanus (Na-ASP-1 and Na-ASP-2) $[17,51]$. The Na-ASP-2 protein has structural and charge similarities to CC-chemokines, suggesting that it might act as a chemokine mimic when released by the infective larvae during tissue migration [52]. For B. malayi, the only SCP/TAPS homologue that has been characterised to date is Bm-VAL-1. Nonetheless, the expression of Bm-VAL-1 was reported to be restricted to L3s, which raises the question of its role in host invasion [16]. SCP/ TAPS molecules identified in Caenorhabditis elegans [19] have been shown to be involved mainly in biological processes, such as antimicrobial activity [53], regulation of longevity, stress resistance [54] and normal fat storage [55]. Thus, the high-level expression of VENOM in A. lumbricoides from infected adults suggests that this protein plays a significant role during infection. However, whether the protein is expressed at the point of initiation, establishment or maintenance during infection warrants further study.

The second highly expressed putative virulence-associated gene in $A$. lumbricoides from infected adults was CADHERIN, expressed 13-fold higher $(P<0.05)$ than in worms from infected children. Cadherins form a superfamily of transmembrane glycoproteins involved in calcium-dependent cell-cell adhesion. These molecules are one of five classes of cell adhesion molecules (CAMs) [56]. The cadherin superfamily includes classical cadherins, protocadherins and atypical cadherins [57]. Generally, cadherins play a significant role in tissue morphogenesis and homeostasis [58, 59], although information on cadherins in parasitic nematodes is limited. Cadherins have been identified in C. elegans, with 12 genes encoding 13 cadherins [60,61]. The main cadherin families that are conserved throughout metazoans include members of the classical cadherin, fat-like cadherin, dachsous, flamingo/CELSR and calystenin families [62]. Unlike other invertebrates, C. elegans lacks protocadherin [63]. The classical cadherin-catenin complex is essential for diverse morphogenetic events during embryogenesis through its interactions with a range of mostly conserved proteins that act to modulate its function. While the other members of the cadherin family in C. elegans are not well characterised, they play clear roles in neuronal development and function [62]. Meanwhile, analysis of the T. canis genome predicted that the T. canis secretome contains at least 870 ES proteins that are proposed to play different roles in host-parasite interaction. Among the ES proteins, 23 are CAMs, including cadherin [26]. In addition, recent comparative genomics analysis of Trichinella spiralis has shown that the cadherin families may be involved in structural remodelling during nurse cell formation [64]. While these molecules are associated with biological processes in C. elegans and most metazoans, the upregulation of CADHERIN in this study does not necessarily imply that it is a virulence factor of A. lumbricoides, as the underlying mechanism of this molecule is poorly understood, particularly in parasitic helminths. Hence, within this context, the expression of CADHERIN may be associated with cell-cell adhesion but further characterisation is required.

The gene encoding for phosphatidylethanolaminebinding protein $(P E B P)$ was also significantly upregulated (fivefold) in A. lumbricoides during the infection of adult individuals. PEBP is highly conserved in organisms, including bacteria, yeast, plants, nematodes, Drosophila and mammals [65]. PEBP controls several signalling pathways, such as inhibition of the MAPK pathway [65] and the NF- $K B$ pathway [66], regulation of heterotrimeric G proteins [67] and serine protease inhibition [68]. In T. canis, PEBP, formerly known as TES-26 but later renamed Tc-PEB-1 [25], is part of the ES proteins and predicted to be involved in immune evasion [18, 26]. Meanwhile, in Trichuris muris (mouse whipworm), Tm16, a whipworm ES protein, has been identified and, based on its amino acid sequence, assigned to the PEBP superfamily. The structure of $\operatorname{Tm} 16$ revealed a prototypical phosphatidylethanolamine-binding-like topology with a large binding cavity capable of accommodating various ligands. This is suggestive of its ability to bind to macromolecules related to the signalling pathway and to transduction or cell migration and regulation. Moreover, it also shares a similar structure to human PEBP (hPEBP) and may have similar functions [69]. Based on evidence from the T. muris study, we suggest that $A$. lumbricoides $P E B P$ also plays a role in the survival of the parasite in the host.

It is possible that the statistically significant expression of VENOM, CADHERIN and PEBP seen in A. lumbricoides from infected adults relative to $A$. lumbricoides from infected children could be a result of differences in 
the host-parasite interaction between adults and children. The immune system is well developed in adults and works efficiently to maintain our defences against many types of pathogens. Similar to other helminth infections, A. lumbricoides induces a highly polarised Th2 immune response [70]. Chronic infections with $A$. lumbricoides in humans are associated with the production of high levels of specific and nonspecific antibodies of all isotypes and immunoglobin (Ig) G subclasses [71, 72], and cytokine response is characterised by the production of Th2 cytokines such as interleukin-4 (IL-4), IL-13, and IL-15 by peripheral blood monocytes and leukocytes [70, $73,74]$. Additionally, a specific IgE has a role in protective immunity in A. lumbricoides infection, either in the initiation of allergic-type inflammatory responses against the parasite or in the amplification of other Th2-mediated mechanisms [75]. However, several other studies have established a clear negative association between parasitespecific IgE levels and infection intensity [76].

The intensity of the infection may depend on various factors, such as host genetics and/or the infected individual's socio-economic or nutritional status and also the host acquired immune response through previous exposure to the parasite. The innate and adaptive immune systems of young children mature more gradually, making children more vulnerable to many pathogens, including parasitic helminths. Nonetheless, adults are also capable of harbouring $A$. lumbricoides, although with fewer worms than children. This implies a slow build-up of specific immunity or variation in susceptibility to infection over time [77]. In this study, expelled worms were obtained from children aged $\leq 5$ years. The intestinal phase of infection is usually asymptomatic, although moderately heavy infections can affect the health, growth and physical fitness of children [78]. It is suggested that children display more symptoms due to the infection compared to adults as their immune system and memory are still underdeveloped to fight the infection, which explains the lower expression of the putative virulenceassociated genes observed in this study. A parallel study on the expression of host immune-related genes during A. lumbricoides infection would provide a better understanding of host-parasite interactions.

As individuals get older, they develop an expanding repertoire of memory $\mathrm{T}$ and $\mathrm{B}$ cells triggered by previous infections [23]. As such, we propose that the immune system of the adult hosts participating in the present study has been primarily moulded by evolution as a result of repeated infection by $A$. lumbricoides, allowing the adults to fight off the infection. However, the helminths are well adapted to their definitive host and adopt various strategies, such as modulating the expression of virulence genes, to overcome or restrict the host defence system by manipulating and modulating host immunity, leading to a failure of the host to eliminate the parasite [14]. One of these virulence factors may be $V E N O M$, which was significantly upregulated in the adult indigenous individuals sampled. As noted above, VENOM is homologous to the $\mathrm{SCP} / \mathrm{TAPS}$ protein in other parasitic worms and SCP/ TAPS proteins are activated in response to host-specific signals produced during the infection process [46].

\section{Conclusion}

In conclusion, we have shown that the selected A. lumbricoides putative virulence-associated genes are overexpressed during an active infection of humans and that expression levels are higher in worms expelled by adults compared to children. Whether the proteins encoded by the significantly overexpressed putative genes (i.e. VENOM, CADHERIN and PEBP) play key biological roles in the infected human host remains to be confirmed. Further studies on host cell mechanisms manipulated by these proteins could facilitate the discovery of new drugs and identification of vaccine targets.

\section{Abbreviations \\ $C_{q}$ : Quantification cycle; ES: Excretory/secretory; GO: Gene ontology; PEBP: Phosphatidylethanolamine-binding protein; SCP/TAPS: Sperm-coat proteins/ Tpx-1/Ag5/PR-1/Sc7; STH: Soil-transmitted helminth.}

\section{Supplementary Information}

The online version contains supplementary material available at https://doi. org/10.1186/s13071-021-04680-y.

Additional file 1: Table S1. Prevalence of STH infections according to the intensity of infections based on Kato-Katz protocol. Table S2. Predicted function(s) of putative A. lumbricoides virulence-associated genes.

Table S3. Primer efficiency for each of the 11 A. lumbricoides putative virulence-associated genes.

\section{Acknowledgements}

We thank all of the indigenous Orang Asli communities who participated voluntarily in this study and to Ms. Nur Amirah Hassan for assistance in sample collection.

\section{Authors' contributions}

NMS, YAL, RN and SN conceived and designed the study. NMS conducted the field work, performed the experiment and analysed the data. The interpretation of the results was performed by NMS with the consultation from SN. Drafting the manuscript was performed by NMS with editing assistance from SN, YAL and RN. All authors contributed to critical revision of the manuscript. All authors read and approved the final manuscript.

\section{Funding}

This work was supported by the University of Malaya Research Grants RP050B17 HTM and PG063-2014B. The funder had no role in study design, data collection, analysis and preparation, or decision to publish the manuscript.

Availability of data and materials

The datasets supporting the conclusions of this article are included within the article and its Additional files. 


\section{Declarations}

Ethics approval and consent to participate

The study protocol was approved by the Ethics Committee of the University of Malaya Medical Centre (UMMC), Malaysia (MEC ID Number: 20144-104).

\section{Consent for publication}

Not applicable.

\section{Competing interest}

The authors declare that they have no competing interests.

\section{Author details}

'Department of Parasitology, Faculty of Medicine, University of Malaya, Kuala Lumpur, Malaysia. ${ }^{2}$ Department of Biological Sciences and Biotechnology, Faculty of Science and Technology, Universiti Kebangsaan Malaysia, Selangor, Malaysia.

Received: 13 January 2021 Accepted: 11 March 2021

Published online: 23 March 2021

\section{References}

1. Vos T, Lim SS, Abbafati C, Abbas KM, Abbasi M, Abbasifard M, et al. Global burden of 369 diseases and injuries in 204 countries and territories, 1990-2019: a systematic analysis for the Global Burden of Disease Study 2019. Lancet. 2020:396:1204-22.

2. Ngui R, Aziz S, Chua KH, Aidil RM, Lee SC, Tan TK, et al. Patterns and risk factors of soil-transmitted Helminthiasis among Orang Asli subgroups in Peninsular Malaysia. Am J Trop Med Hyg. 2015;93:361-70.

3. Rajoo Y, Ambu S, Lim YAL, Rajoo K, Tey SC, Lu CW, et al. Neglected intestinal parasites, malnutrition and associated key factors: a population based cross-sectional study among indigenous communities in Sarawak. Malaysia PLOS ONE. 2017;12:e0170174.

4. Mohd-Shaharuddin N, Lim YAL, Hassan NA, Nathan S, Ngui R. Soil-transmitted helminthiasis among indigenous communities in Malaysia: Is this the endless malady with no solution? Trop Biomed. 2018;35:168-80.

5. Khuroo NS, Khuroo MS, Khuroo MS. Gastric ascariasis presenting as unique dyspeptic symptoms in an endemic area. Am J Gastroenterol. 2010;105:1675-7.

6. Wang P, Li RZ, Huang ZY, Tang CW. Report on 16 cases of small intestine ascariasis diagnosed by capsule endoscopy. Chinese J Parasitol Parasit Dis. 2013;31:242-3.

7. Das AK. Hepatic and biliary ascariasis. J Global Infect Dis. 2014;6:65-72.

8. Al-Mekhlafi MH, Surin J, Atiya AS, Ariffin WA, Mahdy AM, Abdullah HC. Pattern and predictors of soil-transmitted helminth reinfection among aboriginal schoolchildren in rural Peninsular Malaysia. Acta Trop. 2008;107:200-4

9. Supali T, Djuardi Y, Bradley M, Noordin R, Rückert P, Fischer PU. Impact of six rounds of mass drug administration on Brugian filariasis and soiltransmitted helminth infections in eastern Indonesia. PLoS Negl Trop Dis. 2013;7:e2586.

10. Yap P, Du ZW, Wu FW, Jiang JY, Chen R, Zhou XN, et al. Rapid re-infection with soil-transmitted helminths after triple-dose albendazole treatment of school-aged children in Yunnan, People's Republic of China. Am J Trop Med Hyg. 2013;89:23-31.

11. Maizels RM, Yazdanbakhsh M. Immune regulation by helminth parasites: cellular and molecular mechanisms. Nat Rev Immunol. 2003;3:733-44.

12. Allen JE, Maizels RM. Diversity and dialogue in immunity to helminths. Nature Rev Immunol. 2011;11:375-88.

13. Lightowlers $M$, Rickard M. Excretory-secretory products of helminth parasites: Effects on host immune responses. Parasitology. 1988:96:S123-66.

14. Maizels RM, Smits HH, McSorley HJ. Modulation of host immunity by helminths: the expanding repertoire of parasite effector molecules. Immunity. 2018;49:801-18.

15. Hewitson JP, Grainger JR, Maizels RM. Helminth immunoregulation: the role of parasite secreted proteins in modulating host immunity. Mol Biochem Parasitol. 2009;167:1-11.
16. Murray J, Gregory WF, Gomez-Escobar N, Atmadja AK, Maizels RM. Expression and immune recognition of Brugia malayi VAL-1, a homologue of vespid venom allergens and Ancylostoma secreted proteins. Mol Biochem Parasitol. 2001;118:89-96.

17. Goud GN, Bottazzi ME, Zhan B, Mendez S, Deumic V, Plieskatt J, et al. Expression of the Necator americanus hookworm larval antigen Na-ASP-2 in Pichia pastoris and purification of the recombinant protein for use in human clinical trials. Vaccine. 2005;23:4754-64.

18. Maizels RM, Tetteh KK, Loukas A. Toxocara canis: genes expressed by the arrested infective larval stage of a parasitic nematode. Int J Parasitol. 2000;30:495-508

19. Hawdon JM, Narasimhan S, Hotez PJ. Ancylostoma secreted protein 2: cloning and characterization of a second member of a family of nematode secreted proteins from Ancylostoma caninum. Mol Biochem Parasitol. 1999;99:149-65.

20. Ryan S, Shiels J, Taggart CC, Dalton JP, Weldon S. Fasciola hepatica-derived molecules as regulators of the host immune response. Front Immunol. 2020;11:2182

21. Jex AR, Liu S, Li B, Young ND, Hall RS, Li Y, et al. Ascaris suum draft genome. Nature. 2011:479:529-33.

22. Cortés A, Muñoz-Antoli C, Esteban JG, Toledo R. Th2 and Th1 responses: clear and hidden sides of immunity against intestinal helminths. Trends Parasitol. 2017;33:678-93.

23. Simon AK, Hollander GA, McMichael A. Evolution of the immune system in humans from infancy to old age. Proc R Soc B. 2015;282:20143085.

24. Else KJ, Keiser J, Holland CV, Grencis RK, Sattelle DB, Fujiwara RT, et al. Whipworm and roundworm infections. Nat Rev Dis Primers. 2020;6:44.

25. Maizels RM. Toxocara canis: molecular basis of immune recognition and evasion. Vet Parasitol. 2013;193:365-74.

26. Zhu XQ, Korhonen PK, Cai H, Young ND, Nejsum P, von Samson-Himmelstjerna $\mathrm{G}$, et al. Genetic blueprint of the zoonotic pathogen Toxocara canis. Nat Commun. 2015;6:1-8.

27. Marchler-Bauer A, Derbyshire MK, Gonzales NR, Lu S, Chitsaz F, Geer LY, et al. CDD: NCBI's conserved domain database. Nucleic Acids Res. 2014;43:D222-6.

28. Götz S, García-Gómez JM, Terol J, Williams TD, Nagaraj SH, Nueda MJ, et al. High-throughput functional annotation and data mining with the Blast2GO suite. Nucleic Acids Res. 2008;36:3420-35.

29. Shao CC, Xu MJ, Alasaad S, Song HQ, Peng L, Tao JP, et al. Comparative analysis of microRNA profiles between adult Ascaris lumbricoides and Ascaris suum. BMC Vet Res. 2014;10:99.

30. Yoshida A, Nagayasu E, Horii Y, Maruyama H. A novel C-type lectin identified by EST analysis in tissue migratory larvae of Ascaris suum. Parasitol Res. 2012;110:1583-6.

31. Livak KJ, Schmittgen TD. Analysis of relative gene expression data using real-time quantitative PCR and the 2(-delta delta $C(T))$ method. Methods 2001;25:402-8

32. Pullan RL, Smith JL, Jasrasaria R, Brooker SJ. Global numbers of infection and disease burden of soil transmitted helminth infections in 2010 Parasites Vectors. 2014;7:37.

33. Anderson RM, May RM. Infectious diseases of humans: dynamics and control. Oxford: Oxford University Press; 1991.

34. Jia TW, Melville S, Utzinger J, King CH, Zhou XN. Soil-transmitted helminth reinfection after drug treatment: a systematic review and meta-analysis. PLoS Negl Trop Dis. 2012;6:e1621.

35. Park YC, Kim W, Park JK. The complete mitochondrial genome of human parasitic roundworm Ascaris /umbricoides. Mitochondrial DNA. 2011:22:91-3.

36. Easton A, Gao S, Lawton SP, Bennuru S, Khan A, Dahlstrom E, et al. Molecular evidence of hybridization between pig and human Ascaris indicates an interbred species complex infecting humans. Elife. 2020;9:e61562.

37. Vermeire JJ, Cho Y, Lolis E, Bucala R, Cappello M. Orthologs of macrophage migration inhibitory factor from parasitic nematodes. Trends Parasitol. 2008;24:355-63.

38. Chalmers IW, McArdle AJ, Coulson RM, Wagner MA, Schmid R, Hirai H, et al. Developmentally regulated expression, alternative splicing and distinct sub-groupings in members of the Schistosoma mansoni venom allergen-like (SmVAL) gene family. BMC Genomics. 2008;9:89.

39. Cantacessi C, Campbell BE, Visser A, Geldhof P, Nolan MJ, Nisbet AJ, et al. A portrait of the "SCP/TAPS" proteins of eukaryotes-developing a 
framework for fundamental research and biotechnological outcomes. Biotechnol Adv. 2009;27:376-88.

40. Gao B, Allen R, Maier T, Davis EL, Baum TJ, Hussey RS. Molecular characterisation and expression of two venom allergen-like protein genes in Heterodera glycines. Int J Parasitol. 2001;31:1617-25.

41. Zhan B, Liu Y, Badamchian M, Williamson A, Feng J, Loukas A, et al. Molecular characterisation of the Ancylostoma-secreted protein family from the adult stage of Ancylostoma caninum. Int J Parasitol. 2003;33:897-907.

42. Rehman A, Jasmer DP. A tissue specific approach for analysis of membrane and secreted protein antigens from Haemonchus contortus gut and its application to diverse nematode species. Mol Biochem Parasit. 1998;97:55-68.

43. Lizotte-Waniewski M, Tawe W, Guiliano DB, Lu W, Liu J, Williams SA, et al. Identification of potential vaccine and drug target candidates by expressed sequence tag analysis and immunoscreening of Onchocerca volvulus larval cDNA libraries. Infect Immun. 2000;68:3491-501.

44. Tawe W, Pearlman E, Unnasch TR, Lustigman S. Angiogenic activity of Onchocerca volvulus recombinant proteins similar to vespid venom antigen 5. Mol Biochem Parasit. 2000;109:91-9.

45. Stroehlein AJ, Young ND, Hall RS, Korhonen PK, Hofmann A, Sternberg PW, et al. CAP protein superfamily members in Toxocara canis. Parasites Vectors. 2016;9:360.

46. Bethony J, Loukas A, Smout M, Brooker S, Mendez S, Plieskatt J, et al. Antibodies against a secreted protein from hookworm larvae reduce the intensity of hookworm infection in humans and vaccinated laboratory animals. FASEB J. 2005;19:1743-5.

47. Osman A, Wang CK, Winter A, Loukas A, Tribolet L, Gasser RB, et al. Hookworm SCP/TAPS protein structure - a key to understanding hostparasite interactions and developing new interventions. Biotechnol Adv. 2012;30:652-7.

48. Datu BJ, Gasser RB, Nagaraj SH, Ong EK, O'Donoghue P, McInnes R, et al. Transcriptional changes in the hookworm, Ancylostoma caninum, during the transition from a free-living to a parasitic larva. PLoS Negl Trop Dis. 2008;2:e130.

49. Mulvenna J, Hamilton B, Nagaraj SH, Smyth D, Loukas A, Gorman JJ. Proteomics analysis of the excretory/secretory component of the blood-feeding stage of the hookworm, Ancylostoma caninum. Mol Cell Proteomics. 2009;8:109-21.

50. Moyle M, Foster DL, McGrath DE, Brown SM, Laroche Y, De Meutter J, et al. A hookworm glycoprotein that inhibits neutrophil function is a ligand of the integrin CD11b/CD18. J Biol Chem. 1994;269:10008-15.

51. Bin Z, Hawdon J, Qiang S, Hainan R, Huiqing Q, Wei H, et al. Ancylostome secreted protein 1 (ASP-1) homologues in human hookworms. Mol Biochem Parasitol. 1999;1999(1):143-9.

52. Bower MA, Constant SL, Mendez S. Necator americanus: the Na-ASP-2 protein secreted by the infective larvae induces neutrophil recruitment in vivo and in vitro. Exp Parasitol. 2008;1 18:569-75.

53. O'Rourke D, Baban D, Demidova M, Mott R, Hodgkin J. Genomic clusters, putative pathogen recognition molecules, and antimicrobial genes are induced by infection of C. elegans with M. nematophilum. Genome Res. 2006;16:1005-16.

54. Ookuma S, Fukuda M, Nishida E. Identification of a DAF-16 transcriptional target gene, scl-1, that regulates longevity and stress resistance in Caenorhabditis elegans. Curr Biol. 2003;13:427-31.

55. Ashrafi K, Chang FY, Watts JL, Fraser AG, Kamath RS, Ahringer J, et al. Genome-wide RNAi analysis of Caenorhabditis elegans fat regulatory genes. Nature. 2003;421:268-72.

56. Takeichi M. Cadherin cell adhesion receptors as a morphogenetic regulator. Science. 1991;251:1451-5.

57. Halbleib JM, Nelson WJ. Cadherins in development: cell adhesion, sorting, and tissue morphogenesis. Genes Dev. 2006;20:3199-214.

58. Hayashi T, Carthew RW. Surface mechanics mediate pattern formation in the developing retina. Nature. 2004;431:647-52.

59. Chihara D, Nance J. An E-cadherin-mediated hitchhiking mechanism for C. elegans germ cell internalization during gastrulation. Development. 2012;139:2547-56.
60. Hill E, Broadbent ID, Chothia C, Pettitt J. Cadherin superfamily proteins in Caenorhabditis elegans and Drosophila melanogaster. J Mol Biol. 2001;305:1011-24.

61. Cox EA, Tuskey C, Hardin J. Cell adhesion receptors in C. elegans. J Cell Sci. 2004;117:1867-70

62. Hardin J, Lynch A, Loveless T, Pettitt J. Cadherins and their partners in the nematode worm Caenorhabditis elegans. Prog Mol Biol Transl Sci. 2013;116:239-62.

63. Hulpiau P, van Roy F. New insights into the evolution of metazoan cadherins. Mol Biol Evol. 2010;28:647-57.

64. Qu Z, Li W, Zhang N, Li L, Yan H, Li T, et al. Comparative genomic analysis of Trichinella spiralis reveals potential mechanisms of adaptive evolution. Biomed Res Int. 2019: 2948973. https://doi.org/10.1155/2019/2948973.

65. Yeung K, Seitz T, Li S, Janosch P, McFerran B, Kaiser C, et al. Suppression of Raf-1 kinase activity and MAP kinase signalling by RKIP. Nature. 1999:401:173-7.

66. Yeung KC, Rose DW, Dhillon AS, Yaros D, Gustafsson M, Chatterjee D, et al. Raf kinase inhibitor protein interacts with NF-KB-inducing kinase and TAK1 and inhibits NF-kB activation. Mol Cell Biol. 2001;21:7207-17.

67. KroslakT, Koch T, Kahl E, Höllt V. Human phosphatidylethanolaminebinding protein facilitates heterotrimeric $\mathrm{G}$ protein-dependent signaling. J Biol Chem. 2001;276:39772-8.

68. Hengst U, Albrecht H, Hess D, Monard D. The phosphatidylethanolaminebinding protein is the prototype of a novel family of serine protease inhibitors. J Biol Chem. 2001;276:535-40.

69. Liu Z, Kelleher A, Tabb S, Wei J, Pollet J, Hotez PJ, et al. Identification, characterization, and structure of Tm16 from Trichuris muris. J Parasitol Res. 2017;2017:4342789.

70. Cooper PJ, Chico ME, Losonsky G, Sandoval C, Espinel I, Sridhara R, et al. Albendazole treatment of children with ascariasis enhances the vibriocidal antibody response to the live attenuated oral cholera vaccine CVD 103-HgR. J Infect Dis. 2000;182:1199-206.

71. Cooper PJ. Immunity in humans_-Ascaris. In: Kennedy MW, Holland CV, editors. Ascaris—world class parasites. Amsterdam: Kluwer Academic Press; 2002. p. 89-104.

72. King EM, Kim HT, Dang NT, Michael E, Drake L, Needham C, et al. Immuno-epidemiology of Ascaris lumbricoides infection in a high transmission community: antibody responses and their impact on current and future infection intensity. Parasite Immunol. 2005;27:89-96.

73. Geiger SM, Massara CL, Bethony J, Soboslay PT, Carvalho OS, CorrêaOliveira R. Cellular responses and cytokine profiles in Ascaris lumbricoides and Trichuris trichiura infected patients. Parasite Immunol. 2002;24:499-509

74. Fiqueiredo CA, Barreto ML, Rodriques LC, Cooper PJ, Silva NB, Amorim LD, et al. Chronic intestinal helminth infections are associated with immune hyporesponsiveness and induction of a regulatory network. Infect Immun. 2010;78:3160-7.

75. Cooper PJ, Ayre G, Martin C, Rizzo JA, Ponte EV, Cruz AA. Geohelminth infections: a review of the role of $\mathrm{lg} E$ and assessment of potential risks of anti-lgE treatment. Allergy. 2008;63:409-17.

76. McSharry C, Xia Y, Holland CV, Kennedy MW. Natural immunity to Ascaris lumbricoides associated with immunoglobulin E antibody to ABA-1 allergen and inflammation indicators in children. Infect Immun. 1999;67:484-9

77. Dold C, Holland CV. Ascaris and ascariasis. Microbes Infect. 2011;13:632-7.

78. Hall A, Hewitt G, Tuffrey V, De Silva N. A review and meta-analysis of the impact of intestinal worms on child growth and nutrition. Matern Child Nutr. 2008:4:118-236.

\section{Publisher's Note}

Springer Nature remains neutral with regard to jurisdictional claims in published maps and institutional affiliations. 